\title{
Smartphone Application Allowing Physicians to Call Patients Associated with Increased Physician Productivity
}

\author{
Christopher M. Whaley, $P h D^{\top}{ }^{\mathbb{D}}$, Daniel J. Crespin, $P h D^{2}$, and Tisamarie B. Sherry, \\ $M D, P h D^{3}$
}

${ }^{1}$ RAND Corporation, 1776 Main Street, Santa Monica, CA, USA; ${ }^{2}$ RAND Corporation, Boston, MA, USA; ${ }^{3}$ RAND Corporation, Washington, DC, USA.

\begin{abstract}
BACKGROUND: Telehealth and other technologies that enable remote patient-physician communication technologies have widespread use among physicians and other health care providers, but the impacts of these technologies on physician productivity are not well known.

OBJECTIVE: To determine whether a HIPAA-compliant application that allows physicians to call patients from their personal cell phones is associated with an increase in physician productivity.
\end{abstract}

DESIGN, SETTING, AND PARTICIPANTS: We used a $100 \%$ sample of Medicare claims and longitudinal physician-level data to examine whether physician use of a smartphone application that enables physicianpatient phone calls is associated with changes in Medicare patient volume and services. We compared early adopters of the application, 31,577 physicians providing Part B services who initiated use of the application between January 2014 and December 2017, with later adopters, 22,988 physicians who initiated use between January 2018 and July 2019.

MAIN MEASURES: Physician productivity was measured as total Medicare Part B beneficiaries, total Part B services provided, the number of Part B beneficiaries with any evaluation and management (E\&M) service, the total number of E\&M services provided, and the average number of E\&M services provided per beneficiary.

KEY RESULTS: Following application use, there was a 0.52 increase (95\% CI: 0.19 to 0.85 ) in the monthly number of Part B beneficiaries seen. This difference translates to a $0.8 \%$ increase in Part B beneficiaries. Similar increases were observed for the number of unique beneficiaries for which the physician provided E\&M services-a 0.50 increase (95\% CI: 0.27 to 0.73 ) or $1.2 \%$. There was a 0.43 increase (95\% CI: 0.07 to 0.78 ) in monthly E\&M services $(0.7 \%$ increase).

CONCLUSIONS: Physicians who used a freely available smartphone application modestly increased their total Medicare beneficiary volume and total number of E\&M services provided, suggesting potential improvements in physician productivity.

J Gen Intern Med 36(8):2307-14

DOI: $10.1007 / \mathrm{s} 11606-021-06663-2$

(c) Society of General Internal Medicine 2021

\section{INTRODUCTION}

The use of health communication technologies to support remote health care services has emerged as one method to enhance interaction between physicians and patients. ${ }^{1-4}$ By adapting the delivery of health care to available technology, these developments allow physicians to reach patients at mutually convenient times to discuss their care when an office visit is burdensome or unnecessary. Advocates believe that these technologies will not only improve care delivery through better patient compliance ${ }^{2}$ and engagement in decision-making ${ }^{5,6}$ but also increase physician productivity. ${ }^{2,3}$ At the same time, other studies have noted cost and usage barriers to telemedicine, which may impair productivity.

Many health-related technologies speed the flow of information between physicians and patients, which may increase the capacity of physicians to deliver care to new and current patients. However, the impacts of these technologies on physician productivity are not well established. Physicians have noted several implementation barriers of new technologies that may hamper their use, including lacking necessary devices, concerns regarding security and confidentiality, and added workload. ${ }^{7}$ Understanding the impacts of telehealth applications on productivity is especially relevant given the large increased use of telemedicine during the COVID-19 pandemic. $^{8}$

This study examines the impact of a smartphone application that allows physicians to communicate with their patients over their personal cell phones. ${ }^{9}$ The application is HIPAA-compliant and allows physicians to call patients without disclosing their personal cell phone number, thus alleviating both physician and patient privacy concerns. Users of the smartphone application can also specify that calls display the physician's office phone number, which protects physician privacy and may make patients more likely to answer the call. This paper links physician-level data on use of the application with a $100 \%$ sample of Medicare claims data to test whether use of the application is associated with an increase in patients and services.

\section{METHODS}

\section{Doximity Dialer}

Received July 9, 2020

Accepted February 14, 2021

Published online March 5, 2021
Doximity is an online professional medical network for physicians and other clinicians that includes, as of 2018, over one 
million members and over $70 \%$ of US physicians. ${ }^{10}$ In October 2016, Doximity implemented its Dialer application that allows physicians and other health care providers to communicate with patients via their personal cell phone in a HIPAAcompliant environment. Physicians can call patients on their cell phone using the application, but patients see a prespecified number, rather than the physician's personal number. Physicians can customize the pre-specified number to the main office of their clinic or physician group. Patients do not have to download the application.

We obtained physician-level data on the daily volume of calls from October 2016 through December 2019, which we aggregated to the monthly level. For each physician, we identified whether the physician used the application and their total call volume in each month. Specific patient interactions or the contents of the calls are not recorded or tracked, and we are thus unable to examine questions related to specific patient outcomes. For both registered and non-registered physicians, the data combines data from multiple data sources, including data from the Centers for Medicare and Medicaid Services (e.g., the National Plan and Provider Enumeration System (NPPES) National Provider Identifier (NPI) Registry), state licensing boards, specialty societies, and medical schools. Details and validation of the database have been described elsewhere. ${ }^{11-14}$ From these databases, we obtained information on physician age, sex, specialty, years in practice, and practice location.

\section{Medicare Patient Volume Data}

Our second source of data was a 100\% sample of 2014 through 2017 Medicare Fee-for-Service medical claims data. We restricted the sample to Carrier claims for Medicare Part B, which covers clinician office visits. We link these data to the Doximity data using NPIs. Because the Doximity data does not include information on patients, we were unable to link specific patient-physician interactions.

For each NPI and month, we identified the number of distinct Medicare beneficiaries with Part B services and the number of Part B services delivered (defined by counts of HCPCS codes). We also identify total visits and distinct beneficiaries for evaluation and management $(\mathrm{E} \& \mathrm{M})$ visits, which we identify using HCPCS codes 99201 to 99499 . We constructed these monthly measures for all physicians that used the application.

\section{Productivity Measures}

To measure productivity outcomes, we used the following physician-month level outcome measures constructed from 2014 through 2017 Part B claims data: (1) number of Part B beneficiaries, (2) number of Part B services provided, (3) number of Part B beneficiaries with any E\&M services, (4) number of E\&M services provided, and (5) average number of E\&M services provided per beneficiary. We examined E\&M services because we hypothesized that any substitutions between in-person visits and use of the communications technology are most likely to occur for E\&M services.

\section{Statistical Analysis}

To assess the impact of physician use of the smartphone application on physician productivity, we used multivariable linear regressions that measure the monthly change in patient load and services provided following adoption of the application. We compared early adopters, who started using the application between October 2016 and December 2017, to late adopters, who started using the application between January 2018 and July 2019, after our available claims data.

Despite the widespread reach of the platform we study, adoption of health communication technologies remains low in the USA - only $15 \%$ of practices use telemedicine (i.e., the use of mobile technology to deliver clinical services) for patient interactions. ${ }^{15}$ There are a wide variety of factors associated with the adoption of new technologies in health care, including organizational structure and provider attitudes, that are not measurable in our data. ${ }^{16-18}$ Physicians who never used the smartphone application likely vary considerably on unobservable characteristics from physicians who eventually take-up the application, which limits the appropriateness of nonusers as a control group. We therefore hypothesized that the late adopters are more comparable to the early adopters than physicians who never used the tool.

We identified 69,436 physicians providing Part B services at any point between January 2014 December 2017 and who had used the application by July 2019 to contact patients. We limited monthly observations for each physician to a maximum of 3 years pre-use of the application and 1-year post-use, which excludes 1233 physicians. Additionally, we excluded physicians with either a missing age (13,386 physicians), who were younger than 25 (74 physicians) or older than 79 (178 physicians). Our final sample consisted of 54,565 physicians comprised of $31,577(58 \%)$ early adopters and 22,988 (42\%) late adopters.

For each productivity outcome, we estimated a physicianmonth level regression model with an indicator for having used the application, defined as any use, as the key independent variable. Our regression models include fixed effects for each year-month combination (e.g., 48 monthly fixed effects). To control for within-physician differences, we also include fixed effects for physicians (e.g., controls for each individual physician). The physician fixed effects control for any timeinvariant differences between physicians. Thus, our regression models estimate the within-physician difference in outcomes following the first use of the application to contact patients, after controlling for time trends, and relative to physicians who have not used it. Because our control population includes physicians who eventually use the application, but have not yet done so, our results reflect the effect of the application on physicians likely to adopt it. 
We also examine differences by physician age, gender, and specialty. Physician specialty was categorized as primary care, non-surgical specialty, and surgical specialty using the categorization presented in eTable 1 in the Supplement. Furthermore, we tested for evidence of a dose response by determining if physicians with higher rates of application had larger changes in patient volume by separately estimating regression models based on quartiles of application use using total call volume within cohorts defined by first month of use. We clustered standard errors at the physician level. All regression models are estimated using Stata 16. This study was approved by the RAND Institutional Review Board.

\section{Sensitivity Tests}

One potential challenge to the validity of our results is that the physician-level decision to use the application may be correlated with unobserved confounders that also impact patient volume and the volume of services provided. We conducted several sensitivity tests to address this possibility. First, we estimated event study regressions that test for differences in the timing of each outcome before and after application use and examine trends over the 48-month period in 6-month increments. We also re-estimated our main regression model using propensity scores models. Finally, we applied instrumental variables models, which use the October 2016 launch of the tool as an instrument for physician-level use. ${ }^{19}$

\section{RESULTS}

\section{Descriptive Characteristics of Application Use Trends and Application Users}

Figure 1 presents trends in physician use of the smartphone application for physicians providing Part B services. Following the October 2016 launch, 10,413 physicians registered and used the application by the end of 2016. During the same time, 101,668 calls between physicians and patients occurred. The cumulative number of physicians using the application and the number of calls steadily increased reaching 31,577 users and 2.2 million calls by the end of 2017. Our smartphone application data, which extend to 2019, show continued increase in users and calls (eFigure 1 in the Supplement).

Table 1 presents productivity measures and characteristics of application users in the month prior to its launch. Early adopters saw, on average, 63.7 Part B beneficiaries and 43.7 beneficiaries with E\&M services in September 2016 compared to 57.9 Part B beneficiaries and 40.7 beneficiaries with E\&M services per month for late adopters, who did not start using the tool until after 2017. Both differences were statistically significant $(P$ value $<0.05)$. Early adopters also provided 16.0 more Part B services $(P$ value $<0.05)$ per month and 3.7 more E\&M services $(P$ value $<0.05)$ per month than late adopters. However, early adopters (1.30 services) and late adopters (1.31 services) provided a similar average number of E\&M services per beneficiary.

Early adopters (49.4 years) were of similar age as late adopters (48.9 years). Early and late adopters were more likely to be male than female with $72.0 \%$ of early adopters being male compared to $66.5 \%$ of late adopters. The specialty composition of early and late adopters was similar, with nearly half of early and late adopters having a non-surgical specialty. Early adopters were 2.4 percentage points more likely to be in a surgical specialty and 2.1 percentage points less likely to be in primary care. Years since residency were similar between early adopters (20.3 years) and late adopters (19.8 years).

\section{Association Between Smartphone Application Use and Patient Volume}

Table 2 presents regression-adjusted associations between use of the application and the monthly number of Medicare beneficiaries and services. Following physician use of the application, there is a 0.52 increase (95\% CI: 0.19 to 0.85 ) in the monthly number of Part B beneficiaries seen. Based on the baseline mean rate of 61 beneficiaries seen per month, this difference translates to a $0.8 \%$ increase in Part B beneficiaries. Similar increases are observed for the number of unique beneficiaries for which the physician provided E\&M services-a 0.50 increase (95\% CI: 0.27 to 0.73 ) or $1.2 \%$. Monthly total Part B services do not significantly increase after use of the application. There was a 0.43 increase $(95 \%$ CI: 0.07 to 0.78 ) in monthly E\&M services ( $0.7 \%$ increase). The change in the mean number E\&M services per beneficiary was not statistically significant.

Figure 2 presents event-study results that examine regression-adjusted trends in each outcome in the months before and after use of the application, relative to differences in the 6 months prior to use. Months were categorized into 6month periods. We did not find statistically significant trends in each outcome during the months before use of the application. For the monthly number of Part B beneficiaries (panel a), evaluation and management beneficiaries (panel c), and evaluation and management services (panel d), we observed statistically significant increases in the $0-5$ - and 6-12-month periods following use of the application. We observed increased trends in the number of Part B services (panel c), but the result is not statistically significant. We did not observe trends in the number of evaluation and management services per beneficiary (panel d).

\section{Differences in Association by Physician Characteristics}

We found evidence of differences in the association of application use with productivity measures by physician age, gender, and specialty (Table 3 ). Among physicians under age 40 and younger, use of the tool is associated with an increase in the number of monthly Part B patients of 1.8 (95\% CI: 1.1 to 


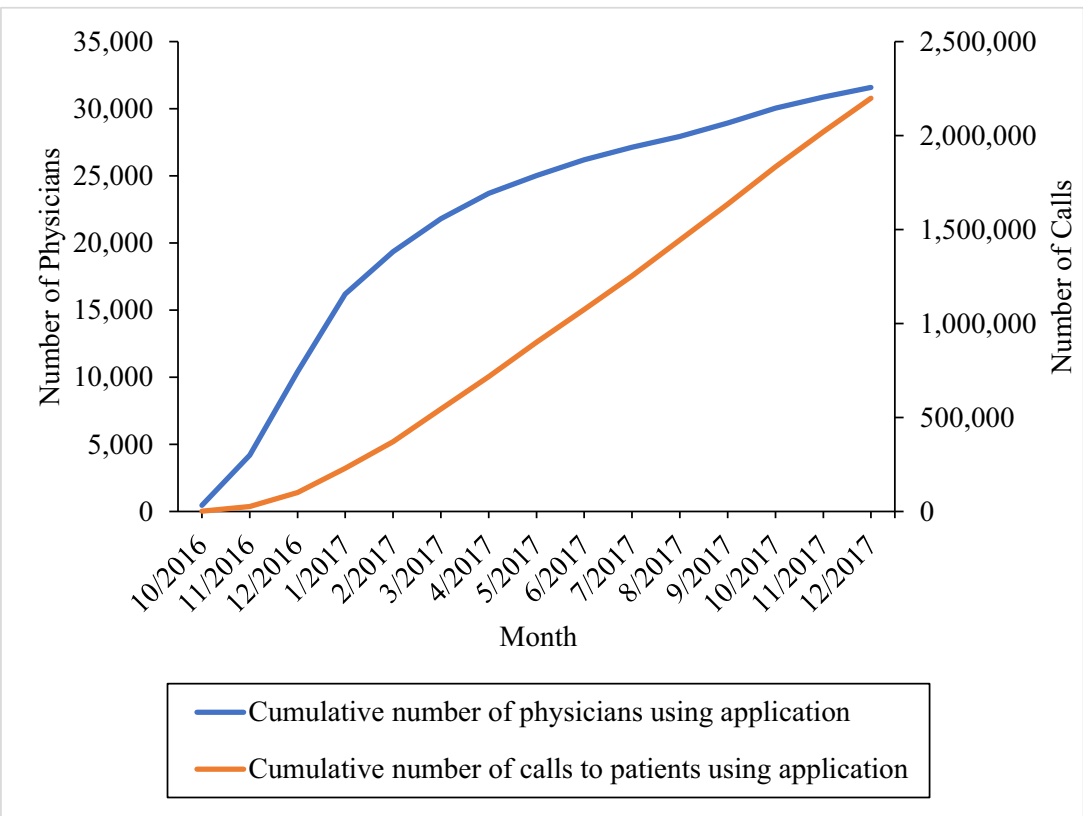

Figure 1 Cumulative number of physicians using the smartphone application volume; includes physicians providing Medicare Part B services

2.5), an increase in monthly Medicare patients with E\&M visits of 1.0 (95\% CI: 0.6 to 1.5$)$, an increase in the number of Part B services performed per month of 4.0 (95\% CI: 2.1 to $6.0)$, and an increase in the number of monthly E\&M services by 1.1 (95\% CI: 0.4 to 1.8 ). Among physicians over age 40, we find an increase in the number of E\&M patients by 0.4 (95\% CI: 0.1 to 0.7 ) but do not find statistically significant changes in the other outcomes.

We observed similar increases in the total number of Part B beneficiaries and the number of Part $\mathrm{B}$ beneficiaries treated for evaluation and management services between male and female physicians. We observed a larger increase in the monthly number of Part B services, 1.6 (95\% CI: 0.3 to 2.9) among female physicians than for male physicians.

We did not find a statistically significant association between application use and patient volume for primary care physicians. Among both non-surgical specialists and specialists, we found statistically significant increases in the number of monthly Part B beneficiaries and beneficiaries with E\&M visits. Among surgical specialists, we also observed a 1.4 (95\% CI: 0.2 to 2.7 ) and 0.6 (95\% CI: 0.3 to 1.0 ) increase in the monthly number of Part $\mathrm{B}$ services and evaluation and management services, respectively.

Finally, we found larger associations for among physicians with increased use of the application. We found no association between use of the application and any of the outcome measures for physicians in the first and second quartiles of application use. Physicians in the third and quartiles of application use had a 0.4 (95\% CI: 0.1 to 0.8 ) and 0.9 (95\% CI: 0.5 to 1.3 ) increase in the number of evaluation and management patients and a 0.6 (95\% CI: 0.01 to 1.2 ) and 1.1 (95\% CI: 0.4 to 1.7$)$ increase in the number of evaluation and management services.

\section{Sensitivity Analyses}

eFigure 2 in the Supplement presents the unadjusted trends in the productivity outcomes relative to when physicians began using the application. We observed similar associations in these unadjusted results. Our regression results are confirmed when using alternative propensity score and instrumental variables modeling approaches (see eAppendix1, eTable 2, and eTable 3 in the Supplement). The results from these sensitivity tests are larger in magnitude than our primary results, suggesting that our results may be conservative.

Table 1 Descriptive Characteristics of Physicians Providing Medicare Part Services in the Month Prior to the Launch of the Smartphone Application (September 2016)

\begin{tabular}{|c|c|c|}
\hline & $\begin{array}{l}\text { Early adopters } \\
(N=\mathbf{3 1}, \mathbf{5 7 7})\end{array}$ & $\begin{array}{l}\text { Late adopters } \\
(N=\mathbf{2 2 , 9 8 8 )}\end{array}$ \\
\hline \multicolumn{3}{|c|}{ Physician productivity measures } \\
\hline $\begin{array}{l}\text { Part B beneficiaries, } \\
\text { mean (SD) }\end{array}$ & $63.7(70.5)$ & $57.9(67.5)$ \\
\hline $\begin{array}{l}\text { Part B services, } \\
\text { mean (SD) }\end{array}$ & $147.4(222.7)$ & $131.4(206.9)$ \\
\hline $\begin{array}{l}\text { Beneficiaries with E\&M } \\
\text { services, mean (SD) }\end{array}$ & $43.7(47.0)$ & $40.7(46.5)$ \\
\hline E\&M services, mean (SD) & $58.1(70.0)$ & $54.4(69.1)$ \\
\hline E\&M services per & $1.30(0.61)$ & $1.31(0.63)$ \\
\hline \multicolumn{3}{|l|}{ beneficiary, mean (SD) } \\
\hline \multicolumn{3}{|l|}{ Physician characteristics } \\
\hline Âge, mean (SD), years & $49.4(10.0)$ & $48.9(10.0)$ \\
\hline Male $(\%)$ & 72.0 & 66.5 \\
\hline Female $(\%)$ & 28.0 & 33.5 \\
\hline Primary care $(\%)$ & 30.2 & 32.3 \\
\hline Non-surgical specialty (\%) & 49.2 & 49.5 \\
\hline Surgical specialty $(\%)$ & 20.6 & 18.2 \\
\hline $\begin{array}{l}\text { Years since residency, } \\
\text { mean (SD), years }\end{array}$ & $20.3(10.2)$ & $19.8(10.1)$ \\
\hline
\end{tabular}

$E \& M$, evaluation and management

Descriptive statistics exclude physicians who did not enter sample until after September 2016 
Table 2 Regression-Adjusted Association Between Smartphone Application Use and Productivity Measures

\begin{tabular}{|c|c|c|c|c|c|c|c|c|c|c|}
\hline & \multicolumn{2}{|c|}{$\begin{array}{l}\text { Number of Part B } \\
\text { beneficiaries }\end{array}$} & \multicolumn{2}{|c|}{$\begin{array}{l}\text { Number of Part B } \\
\text { services }\end{array}$} & \multicolumn{2}{|c|}{$\begin{array}{l}\text { Number of E\&M } \\
\text { beneficiaries }\end{array}$} & \multicolumn{2}{|c|}{$\begin{array}{l}\text { Number of } E \& M \\
\text { services }\end{array}$} & \multicolumn{2}{|c|}{$\begin{array}{l}\text { Average E\&M services } \\
\text { per beneficiary }\end{array}$} \\
\hline & $\begin{array}{l}\text { Coefficient } \\
(95 \% \text { CI })^{a}\end{array}$ & $\begin{array}{l}P \\
\text { value }\end{array}$ & $\begin{array}{l}\text { Coefficient } \\
(95 \% \text { CI })^{a}\end{array}$ & $\begin{array}{l}P \\
\text { value }\end{array}$ & $\begin{array}{l}\text { Coefficient } \\
(95 \% \text { CI })^{a}\end{array}$ & $\begin{array}{l}P \\
\text { value }\end{array}$ & $\begin{array}{l}\text { Coefficient } \\
(95 \% \text { CI })^{a}\end{array}$ & $\begin{array}{l}P \\
\text { value }\end{array}$ & $\begin{array}{l}\text { Coefficient } \\
(95 \% \text { CI })^{a}\end{array}$ & $\begin{array}{l}P \\
\text { value }\end{array}$ \\
\hline $\begin{array}{l}\text { Post } \\
\text { application } \\
\text { use }\end{array}$ & $\begin{array}{l}0.521(0.194 \\
\text { to } 0.847)\end{array}$ & 0.002 & $\begin{array}{l}0.755 \\
(-0.218 \text { to } \\
1.728)\end{array}$ & 0.128 & $\begin{array}{l}0.497(0.268 \\
\text { to } 0.725)\end{array}$ & $<0.001$ & $\begin{array}{l}0.425(0.068 \\
\text { to } 0.781)\end{array}$ & 0.019 & $\begin{array}{l}-0.00335 \\
(-0.00705 \text { to } \\
0.00034)\end{array}$ & 0.075 \\
\hline Observations & $1,700,988$ & & $1,700,988$ & & $1,591,489$ & & $1,591,489$ & & $1,591,489$ & \\
\hline Mean & 61.4 & & 137.2 & & 42.8 & & 57.8 & & 1.3 & \\
\hline
\end{tabular}

$E \& M$, evaluation and management; $C I$, confidence interval

${ }^{a}$ Adjusted for year and month and physician fixed effects. Standard errors clustered at the physician level

\section{DISCUSSION}

Many new health communication technologies aim to facilitate virtual interactions between physicians and patients at times that are convenient to both parties. Advocates of these advances emphasize that among several benefits to health care, these advances can improve physician productivity by increasing their capacity to treat patients. ${ }^{2,}{ }^{3}$ However, some physicians may be reluctant to use such technologies due to privacy concerns related to both their own personal

(a) Number of Part B Beneficiaries

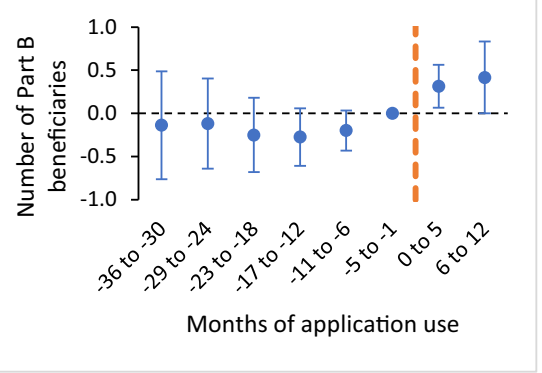

(b) Number of Part B Services

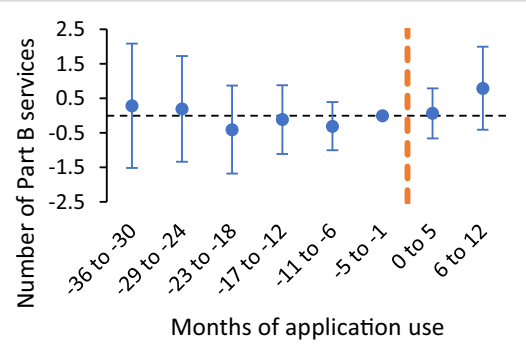

(c) Number of E\&M Beneficiaries

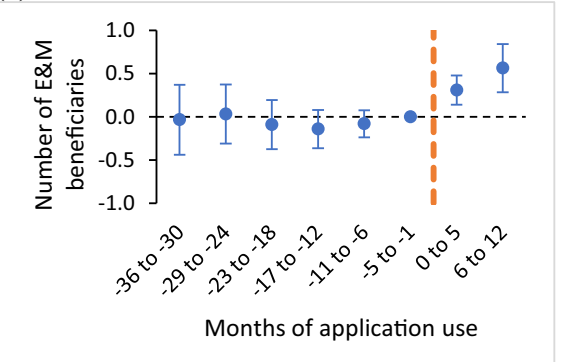

information and patients' health information. ${ }^{7}$ The smartphone application we study allows physicians to contact patients while masking their own personal contact information in a HIPAA-compliant environment.

We found a meaningful association between use of the application and increases in Medicare beneficiary volume as well as total evaluation and management services provided. The largest associations between use of the application and changes in patient volume were observed for younger

(d) Number of E\&M Services

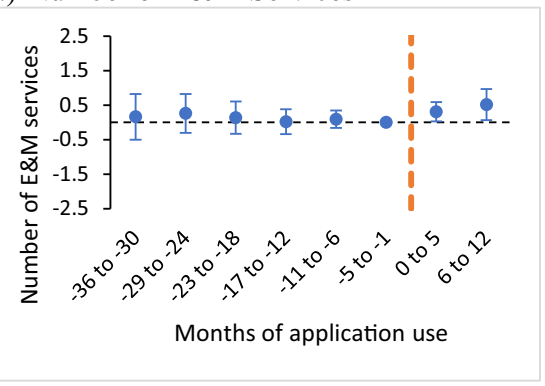

(e) Average E\&M Services per Beneficiary

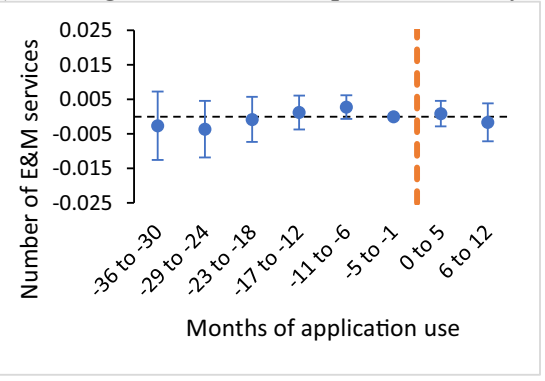

Figure 2 a-e Association between smartphone application use and productivity measures, event study regression results; adjusted for year and month and physician fixed effects. Standard errors clustered at the physician level. E\&M, evaluation and management. 
Table 3 Regression-Adjusted Physician-Level Differences in Association Between Smartphone Application Use and Productivity Measures

\begin{tabular}{|c|c|c|c|c|c|c|c|c|c|c|}
\hline & \multicolumn{2}{|c|}{$\begin{array}{l}\text { Number of Part B } \\
\text { beneficiaries }\end{array}$} & \multicolumn{2}{|c|}{$\begin{array}{l}\text { Number of Part B } \\
\text { services }\end{array}$} & \multicolumn{2}{|c|}{$\begin{array}{l}\text { Number of E\&M } \\
\text { beneficiaries }\end{array}$} & \multicolumn{2}{|c|}{$\begin{array}{l}\text { Number of E\&M } \\
\text { services }\end{array}$} & \multicolumn{2}{|c|}{$\begin{array}{l}\text { Average E\&M } \\
\text { services per } \\
\text { beneficiary }\end{array}$} \\
\hline & $\begin{array}{l}\text { Coefficient } \\
(95 \% \text { CI })^{\mathrm{a}}\end{array}$ & $\begin{array}{l}P \\
\text { value }\end{array}$ & $\begin{array}{l}\text { Coefficient } \\
(95 \% \mathrm{CI})^{\mathrm{a}}\end{array}$ & $\begin{array}{l}P \\
\text { value }\end{array}$ & $\begin{array}{l}\text { Coefficient } \\
(95 \% \text { CI })^{a}\end{array}$ & $\begin{array}{l}P \\
\text { value }\end{array}$ & $\begin{array}{l}\text { Coefficient } \\
(95 \% \text { CI })^{a}\end{array}$ & $\begin{array}{l}P \\
\text { value }\end{array}$ & $\begin{array}{l}\text { Coefficient } \\
(95 \% \text { CI })^{a}\end{array}$ & $\begin{array}{l}P \\
\text { value }\end{array}$ \\
\hline \multicolumn{11}{|c|}{ Physician age } \\
\hline $\begin{array}{l}\text { Age } 40 \\
\text { and } \\
\text { younger }\end{array}$ & $\begin{array}{l}1.793(1.109 \\
\text { to } 2.477)\end{array}$ & $<0.001$ & $\begin{array}{l}4.046(2.060 \\
\text { to } 6.032)\end{array}$ & $<0.001$ & $\begin{array}{l}1.026(0.580 \\
\text { to } 1.472)\end{array}$ & $<0.001$ & $\begin{array}{l}1.073(0.382 \\
\text { to } 1.765)\end{array}$ & 0.002 & $\begin{array}{l}-0.0065 \\
(-0.0159 \text { to } \\
0.0029)\end{array}$ & 0.177 \\
\hline $\begin{array}{l}\text { Over age } \\
40\end{array}$ & $\begin{array}{l}0.257 \\
(-0.112 \text { to } \\
0.626)\end{array}$ & 0.172 & $\begin{array}{l}0.091 \\
(-1.021 \text { to } \\
1.203)\end{array}$ & 0.872 & $\begin{array}{l}0.405(0.143 \\
\text { to } 0.668)\end{array}$ & 0.003 & $\begin{array}{l}0.313 \\
(-0.982 \text { to } \\
0.724)\end{array}$ & 0.136 & $\begin{array}{l}-0.0026 \\
(-0.0066 \text { to } \\
0.0013)\end{array}$ & 0.190 \\
\hline \multicolumn{11}{|c|}{ Physician sex } \\
\hline Female & $\begin{array}{l}0.640(0.159 \\
\text { to } 1.120)\end{array}$ & 0.009 & $\begin{array}{l}1.592(0.280 \\
\text { to } 2.904)\end{array}$ & 0.017 & $\begin{array}{l}0.496(0.113 \\
\text { to } 0.880)\end{array}$ & 0.011 & $\begin{array}{l}0.428 \\
(-0.132 \text { to } \\
0.988)\end{array}$ & 0.134 & $\begin{array}{l}-0.0054 \\
(-0.0124 \text { to } \\
0.0016)\end{array}$ & 0.132 \\
\hline Male & $\begin{array}{l}0.516(0.098 \\
\text { to } 0.933)\end{array}$ & 0.016 & $\begin{array}{l}0.572 \\
(-0.692 \text { to } \\
1.836)\end{array}$ & 0.375 & $\begin{array}{l}0.553(0.269 \\
\text { to } 0.837)\end{array}$ & $<0.001$ & $\begin{array}{l}0.496(0.045 \\
\text { to } 0.946)\end{array}$ & 0.031 & $\begin{array}{l}-0.0024 \\
(-0.0068 \text { to } \\
0.0019)\end{array}$ & 0.274 \\
\hline \multicolumn{11}{|c|}{ Physician specialty } \\
\hline $\begin{array}{l}\text { Primary } \\
\text { care }\end{array}$ & $\begin{array}{l}0.446 \\
(-0.111 \text { to } \\
1.002)\end{array}$ & 0.117 & $\begin{array}{l}-0.045 \\
(-1.874 \text { to } \\
1.784)\end{array}$ & 0.961 & $\begin{array}{l}0.474 \\
(-0.025 \text { to } \\
0.972)\end{array}$ & 0.063 & $\begin{array}{l}0.561 \\
(-0.262 \text { to } \\
1.384)\end{array}$ & 0.182 & $\begin{array}{l}-0.0036 \\
(-0.110 \text { to } \\
0.0037)\end{array}$ & 0.331 \\
\hline $\begin{array}{l}\text { Non- } \\
\text { surgical } \\
\text { specialist }\end{array}$ & $\begin{array}{l}0.559(0.168 \\
\text { to } 1.102)\end{array}$ & 0.043 & $\begin{array}{l}0.812 \\
(-0.751 \text { to } \\
2.376)\end{array}$ & 0.309 & $\begin{array}{l}0.537(0.211 \\
\text { to } 0.864)\end{array}$ & 0.001 & $\begin{array}{l}0.253 \\
(-0.245 \text { to } \\
0.752)\end{array}$ & 0.319 & $\begin{array}{l}-0.0068 \\
(-0.0125 \text { to } \\
0.0011)\end{array}$ & 0.019 \\
\hline $\begin{array}{l}\text { Surgical } \\
\text { specialist }\end{array}$ & $\begin{array}{l}0.537(0.078 \\
\text { to } 0.996)\end{array}$ & 0.022 & $\begin{array}{l}1.430(0.203 \\
\text { to } 2.657)\end{array}$ & 0.022 & $\begin{array}{l}0.457(0.146 \\
\text { to } 0.768)\end{array}$ & 0.004 & $\begin{array}{l}0.646(0.275 \\
\text { to } 1.017)\end{array}$ & 0.001 & $\begin{array}{l}0.0052 \\
(0.0002 \text { to } \\
0.0103)\end{array}$ & 0.043 \\
\hline \multicolumn{11}{|c|}{ Intensity of application use (quartiles of use) } \\
\hline $\begin{array}{l}1 \text { st } \\
\text { quartile }\end{array}$ & $\begin{array}{l}-0.357 \\
(-1.324 \text { to } \\
0.611)\end{array}$ & 0.47 & $\begin{array}{l}-2.217 \\
(-4.832 \text { to } \\
0.399)\end{array}$ & 0.097 & $\begin{array}{l}-0.110 \\
(-0.828 \text { to } \\
0.607)\end{array}$ & 0.763 & $\begin{array}{l}-0.772 \\
(-1.916 \text { to } \\
0.371)\end{array}$ & 0.158 & $\begin{array}{l}-0.00352 \\
(-0.0152 \text { to } \\
0.00813)\end{array}$ & 0.66 \\
\hline $\begin{array}{l}\text { 2nd } \\
\text { quartile }\end{array}$ & $\begin{array}{l}-0.346 \\
(-0.945 \text { to } \\
0.252)\end{array}$ & 0.47 & $\begin{array}{l}-0.952 \\
(-2.633 \text { to } \\
0.730)\end{array}$ & 0.267 & $\begin{array}{l}-0.203 \\
(-0.620 \text { to } \\
0.215)\end{array}$ & 0.342 & $\begin{array}{l}-0.604 \\
(-1.238 \text { to } \\
0.0312)\end{array}$ & 0.183 & $\begin{array}{l}-0.00775 \\
(-0.0149 \text { to } \\
-0.000641)\end{array}$ & 0.103 \\
\hline $\begin{array}{l}\text { 3rd } \\
\text { quartile }\end{array}$ & $\begin{array}{l}0.337 \\
(-0.225 \text { to } \\
0.899)\end{array}$ & 0.239 & $\begin{array}{l}-0.0646 \\
(-1.913 \text { to } \\
1.784)\end{array}$ & 0.945 & $\begin{array}{l}0.462 \\
(0.0842 \text { to } \\
0.841)\end{array}$ & 0.017 & $\begin{array}{l}0.605 \\
(0.00797 \text { to } \\
1.202)\end{array}$ & 0.019 & $\begin{array}{l}0.00380 \\
(-0.00235 \text { to } \\
0.00996)\end{array}$ & 0.185 \\
\hline $\begin{array}{l}\text { 4th } \\
\text { quartile }\end{array}$ & $\begin{array}{l}1.221(0.668 \\
\text { to } 1.773)\end{array}$ & $<0.001$ & $\begin{array}{l}2.553(0.932 \\
\text { to } 4.173)\end{array}$ & $<0.001$ & $\begin{array}{l}0.886(0.503 \\
\text { to } 1.269)\end{array}$ & $<0.001$ & $\begin{array}{l}1.054(0.453 \\
\text { to } 1.656)\end{array}$ & $<0.001$ & $\begin{array}{l}-0.00379 \\
(-0.0100 \text { to } \\
0.00246)\end{array}$ & 0.751 \\
\hline
\end{tabular}

$E \& M$, evaluation and management; $C I$, confidence interval

${ }^{a}$ Adjusted for year and month and physician fixed effects. Standard errors clustered at the physician level

physicians and specialist physicians. One potential explanation for this finding is that use of the application allows physicians to free up time during normal office hours, providing more time for patient visits. Prior to the COVID-19 pandemic, many telephone-only visits were not reimbursed by Medicare or private insurers - even despite this, research has shown that such telephonic and virtual visits can substitute for in-person office visits. ${ }^{20-22}$ In one study of a single hospital and approximately 150 surgery patients, the use of postoperative telephone follow-up opened up available in-office visits slots resulting in the hospital taking on new patients. ${ }^{20}$ Besides substituting for in-person visits, the application eases the ability of physician to make phone calls before or after typical clinic hours, rather than while at the office, as another avenue to free up time to take on more patients. Likewise, younger physicians may be more technologically savvy and used to using similar applications in other aspects of their practice or daily lives.

Our analysis could have several limitations. First, there may be unobserved confounders that occurred during the time of this study that also changed physician productivity. However, our event study analysis showed no evidence of trends in productivity prior to application use, suggesting any unobservable confounders did not have a significant effect on productivity prior to application use. We also found evidence of a dose response, and larger changes for physicians with increased use of the application. In addition, our results were confirmed when using alternative propensity score and instrumental variables modeling approaches. Second, although we found increases in broad measures productivity, these effects may be concentrated in specific types of patients or visits. Future research could explore this possibility be examining specific procedures or diagnoses. Third, we compared early adopters of the application to late adopters, which may limit the generalizability of our results to physicians who did not use the application and may also be less likely to adopt similar health communication technologies.

These results should also be interpreted in the context of alternative physician technologies. Other studies have found 
that electronic health records can lead to reductions in physician productivity, especially during early stages of use when physicians and staff must take the time to learn how to use and incorporate electric health records into treating patients. ${ }^{23}$ This study shows that active use of the application is associated with improved physician productivity within the first 6 months of use, though changes are modest in magnitude.

Potential explanations for the difference in results could stem from the numerous barriers to successful implementation of many health information and communication technologies, including electronic health records and areas of telehealth and telemedicine. ${ }^{24,}{ }^{25}$ In fact, one literature review cited 68 unique barriers to implementing electronic health records with cost and needed technical support being the most frequent. ${ }^{25}$ Moreover, many payers, including Medicare, and health systems that employ physicians require physicians to use some of these technologies. Without considering physician compatibility as a priority, the impact of these technologies on productivity may be limited. In contrast, the application we study is free of charge, voluntary to physicians and physician engagement is the key aim.

The impact of the application on patient outcomes is unclear. Prior studies have shown that health information and communication technologies can improve patient engagement and physician-patient communication ${ }^{6,26}$, which are often associated with improved health outcomes and patient satisfaction. ${ }^{27-29}$ Future work should examine if patients of physicians who use these tools report higher satisfaction with their care or have fewer potentially unnecessary acute services. Future work should also examine the impacts on physician work-life balance and burnout. Finally, the COVID-19 pandemic has led to rapid adoption of telemedicine and substitution of in-person care for care delivered virtually. ${ }^{30}$ Future studies should examine the efficacy of this substitution, and how the use of telemedicine during the COVID-19 pandemic has impact patients and providers.

Corresponding Author: Christopher M. Whaley, PhD; RAND Corporation, 1776 Main Street, Santa Monica, CA 90401, USA (e-mail: cwhaley@rand.org).

Supplementary Information The online version contains supplementary material available at https://doi.org/10.1007/s11606-02106663-2.

\section{Declarations:}

Conflict of Interest: Support was provided by the National Institutes on Aging (1K01AG061274, Dr. Whaley). Access to Medicare data was provided through the RAND Center of Excellence on Health System Performance, which is funded through a cooperative agreement (1U19HS024067-01) with the Agency for Healthcare Research and Quality. Dr. Whaley reports consulting fees unrelated to this paper from Doximity. The funding sources had no role in the design and conduct of the study; collection, management, analysis, and interpretation of the data; and preparation, review, or approval of the manuscript.

\section{REFERENCES}

1. Institute of Medicine. The Role of Telehealth in an Evolving Health Care Environment: Workshop Summary. reprint ed: National Academies Press; 2012

2. Kvedar J, Coye MJ, Everett W. Connected health: a review of technologies and strategies to improve patient care with telemedicine and telehealth. Health Aff (Millwood). 2014;33(2):194-199.

3. Dorsey ER, Topol EJ. State of Telehealth. N Engl J Med. 2016;375(2):154-161.

4. Henry BW, Block DE, Ciesla JR, McGowan BA, Vozenilek JA. Clinician behaviors in telehealth care delivery: a systematic review. Adv Health Sci Educ Theory Pract. 2017;22(4):869-888.

5. Grando M, Rozenblum R, Bates D. Information Technology for Patient Empowerment in Healthcare. Walter de Gruyter GmbH \& Co KG; 2015.

6. Sawesi S, Rashrash M, Phalakornkule K, Carpenter JS, Jones JF. The Impact of Information Technology on Patient Engagement and Health Behavior Change: A Systematic Review of the Literature. JMIR Med Inform. 2016;4(1):e1.

7. Schreiweis B, Pobiruchin M, Strotbaum V, Suleder J, Wiesner M, Bergh B. Barriers and Facilitators to the Implementation of eHealth Services: Systematic Literature Analysis. J Med Internet Res. 2019;21(11):e14197.

8. Wosik J, Fudim M, Cameron B, et al. Telehealth transformation: COVID-19 and the rise of virtual care. J Am Med Inform Assoc. 2020;27(6):957-962.

9. Doximity Inc. https://www.doximity.com/clinicians/download/dialer. Published 2020. Accessed.

10. Doximity Inc. Doximity Reaches Over $70 \%$ of U.S. Physicians. https:// blog.doximity.com/articles/doximity-reaches-over-70-of-u-s-physicians. Published 2017. Accessed.

11. Jena AB, Khullar D, Ho O, Olenski AR, Blumenthal DM. Sex Differences in Academic Rank in US Medical Schools in 2014. JAMA 2015;314(11):1149-1158.

12. Khullar D, Blumenthal DM, Olenski AR, Jena AB. U.S. Immigration Policy and American Medical Research: The Scientific Contributions of Foreign Medical Graduates. Ann Intern Med. 2017;167(8):584586.

13. Tsugawa Y, Jena AB, Orav EJ, et al. Age and sex of surgeons and mortality of older surgical patients: observational study. BMJ. 2018;361:k1343.

14. Tsugawa $\mathbf{Y}$, Kato $\mathbf{H}$, Jha $\mathbf{A K}$, et al. Characteristics of Physicians Who Adopted Medicare's New Advance Care Planning Codes in the First Year. J Gen Intern Med. 2019.

15. Kane CK, Gillis K. The Use Of Telemedicine By Physicians: Still The Exception Rather Than The Rule. Health Aff (Millwood). 2018;37(12):1923-1930.

16. Police R, Foster T, Wong $\mathbf{K}$. Adoption and use of health information technology in physician practice organisations: systematic review. Informatics in Primary Care. 2011;18:245-258.

17. Ross J, Stevenson F, Lau R, Murray E. Factors that influence the implementation of e-health: a systematic review of systematic reviews (an update). Implement Sci. 2016;11(1):146.

18. O'Donnell A, Kaner E, Shaw C, Haighton C. Primary care physicians' attitudes to the adoption of electronic medical records: a systematic review and evidence synthesis using the clinical adoption framework. BMC Med Inform Decis Mak. 2018;18(1): 101.

19. Maciejewski ML, Brookhart MA. Using Instrumental Variables to Address Bias From Unobserved Confounders. JAMA. 2019;321(21):2124-2125.

20. Hwa K, Wren SM. Telehealth follow-up in lieu of postoperative clinic visit for ambulatory surgery: results of a pilot program. JAMA Surg. 2013;148(9):823-827.

21. Kummerow Broman K, Roumie CL, Stewart MK, et al. Implementation of a Telephone Postoperative Clinic in an Integrated Health System. J Am Coll Surg. 2016;223(4):644-651.

22. Armstrong KA, Coyte PC, Brown M, Beber B, Semple JL. Effect of Home Monitoring via Mobile App on the Number of In-Person Visits Following Ambulatory Surgery: A Randomized Clinical Trial. JAMA Surg. 2017;152(7):622-627.

23. Kruse CS, Stein A, Thomas $\mathbf{H}$, Kaur $\mathbf{H}$. The use of Electronic Health Records to Support Population Health: A Systematic Review of the Literature. J Med Syst. 2018;42(11):214.

24. de Grood C, Raissi A, Kwon Y, Santana MJ. Adoption of e-health technology by physicians: a scoping review. J Multidiscip Healthc. 2016;9:335-344 
25. Kruse CS, Kristof C, Jones B, Mitchell E, Martinez A. Barriers to Electronic Health Record Adoption: a Systematic Literature Review. J Med Syst. 2016;40(12):252.

26. Gordon CR, Rezzadeh KS, Li A, et al. Digital mobile technology facilitates HIPAA-sensitive perioperative messaging, improves physicianpatient communication, and streamlines patient care, Patient Saf Surg. 2015;9:21.

27. Sherwood A, Brinkmann J, Fatone S. Review of Benefits to Practitioners of Using Good Patient-Practitioner Communication. J Prosthet Orthot. 2018;20(1):5-12.

28. Hibbard $\mathbf{J H}$, Greene $\mathbf{J}$. What the evidence shows about patient activation: better health outcomes and care experiences; fewer data on costs. Health Aff (Millwood). 2013;32(2):207-214.
29. Street RL Jr. How clinician-patient communication contributes to health improvement: modeling pathways from talk to outcome. Patient Educ Couns. 2013;92(3):286-291.

30. Whaley CM, Pera MF, Cantor J, et al. Changes in Health Services Use Among Commercially Insured US Populations During the COVID-19 Pandemic. JAMA Netw Open. 2020;3(11):e2024984.

Publisher's Note: Springer Nature remains neutral with regard to jurisdictional claims in published maps and institutional affiliations. 